Khairuddin Abdul Rashid

Kiyoshi Kobayashi

Sharina Farihah Hasan

Masamitsu Onishi

editors

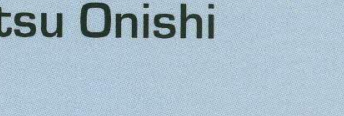

\title{
CONCEPT AND APPLICATION OF
}

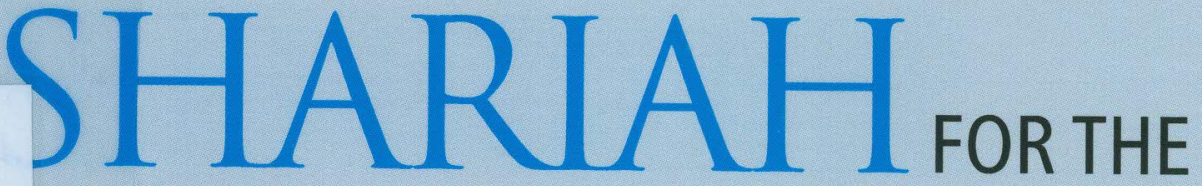

:ONSTRUCTION INDUSTRY

Shariah Compliance in Construction Contracts, Project Finance and Risk Management 


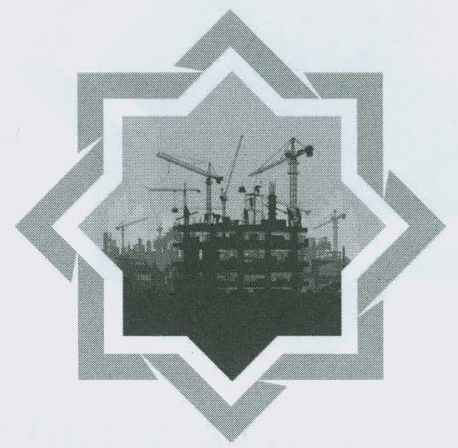

\section{CONCEPT AND APPLICATION OF SHARIAH оов тнE $_{\text {TH }}$ CONSTRUCTION INDUSTRY}

Shariah Compliance in Construction Contracts, Project Finance and Risk Management 


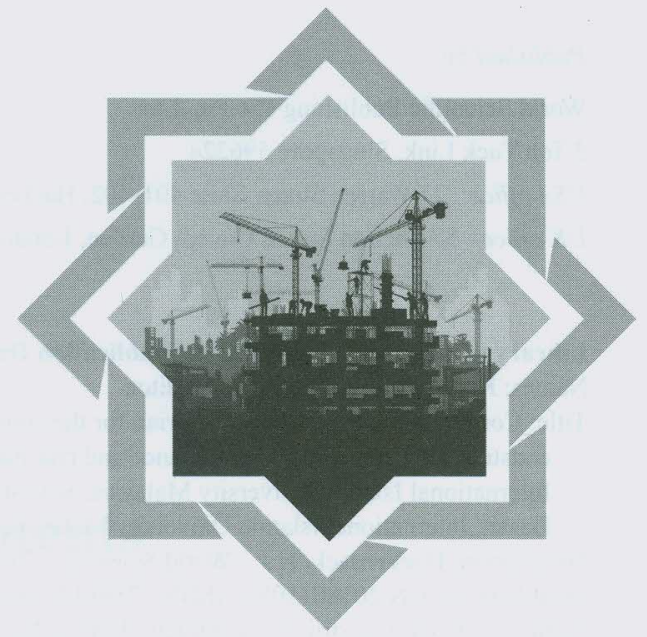

\section{CONCEPT AND APPLICATION OF}

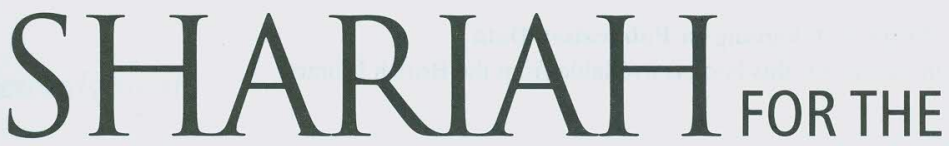

\section{CONSTRUCTION INDUSTRY}

Shariah Compliance in Construction Contracts, Project Finance and Risk Management

\section{Editors}

Khairuddin Abdul Rashid

International Islamic University Malaysia, Malaysia

Kiyoshi Kobayashi

Kyoto University, Japan

Sharina Farihah Hasan

International Islamic University Malaysia, Malaysia

Masamitsu Onishi

Kyoto University, Japan 
5 Toh Tuck Link, Singapore 596224

USA office: 27 Warren Street, Suite 401-402, Hackensack, NJ 0760

UK office: 57 Shelton Street, Covent Garden, London WC2H $9 \mathrm{HE}$

\section{Library of Congress Cataloging-in-Publication Data}

Names: Khairuddin, Abdul Rashid, editor.

Title: Concept and application of Shariah for the construction industry : Shariah compliance in

construction contracts, project finance and risk management / Editors: Khairuddin Abdul Rashid,

International Islamic University Malaysia, Kiyoshi Kobayashi, Kyoto University, Sharina Farihah

Hasan, International Islamic University Malaysia, Masamitsu Onishi, Kyoto University.

Description: Hackensack, N.J. : World Scientific, 2018. | Includes index.

Identifiers: LCCN 2018015080 | ISBN 9789813238909 (hardcover)

Subjects: LCSH: Construction contracts (Islamic law) | Dispute resolution (Law)

Classification: LCC KBP893.3.C65 C66 2018 | DDC 624.068/1--dc23

LC record available at https://lcen.loc.gov/2018015080

\section{British Library Cataloguing-in-Publication Dat}

A catalogue record for this book is available from the British Library.

\section{Copyright (0) 2019 by World Scientific Publishing Co. Pte. Ltd.}

All rights reserved. This book, or parts thereof, may not be reproduced in any form or by any means, electronic or mechanical, including photocopying, recording or any information storage and retrieval system now known or to be invented, without written permission from the publisher.

For photocopying of material in this volume, please pay a copying fee through the Copyright Clearance Center, Inc., 222 Rosewood Drive, Danvers, MA 01923, USA. In this case permission to photocopy is not required from the publisher.

Disclaimer. The book is published on the understanding that the authors are solely responsible for the statements made and opinions expressed in it and that its publication does not necessarily imply that such statements and/or opinions are or reflect the views or the opinions of the editors and publisher. Whilst every effort has been made to ensure that the statements made and the opinions expressed in this publication provide a safe and accurate guide, no liability or responsibility can be accepted in this respect by the author or editors or publisher.

For any available supplementary material, please visit

https://www.worldscientific.com/worldscibooks/10.1142/10957\#t=supp/

Desk Editor: Tay Yu Shan Copy No: 1110.0396579

Typeset by Stallion Press Initial.Date: BAA $31 / 5 / 19$

\section{Contents}

Preface

List of Tables

List of Appendices

1 Shariah and Its Meaning in Islam 
2 Understanding of the Shariah in Regards to Construction

MOHAMAD AKRAM Laldin

3 Promoting Efficiency in Construction Practices:

Lessons from Shariah

AINUL JARIA Maidin - $1875 / 72632$

4 Shariah-Compliant Construction Marketing:

Development of a New Theory

KHAIRUDDIN Abdul Rashid and Christopher

Nigel PREECE $-5137 / 72633$

\section{Part 2: Shariah-Compliant Construction Contract: Concept and Application}

5 Shariah-Compliant Contract: Concept and Application for Construction Works

KHAIRUDDIN Abdul Rashid - $5137 / 72634$

6 Istisna' Model for Construction Works' Contracts KHAIRUDDIN Abdul Rashid $-5137 / 72635$

7 Validity of Istisna' for Construction Works Contracts KHAIRUDDIN Abdul Rashid - 5137/72636

8 The Application of Limited Liability in Construction Contracts from the Malaysian Law and Shariah Perspectives

ZUHAIRAH ARIFF Abdul Ghadas

9 The Application of Shariah Principles of ADR in the Malaysian Construction Industry
Part 3: Shariah-Compliant Project Finance and Risk Management

10 The 3 Rs in Islamic Project Finance: Its Relevance Under Maqasid al-Shariah

Etsuaki YOSHIDA

11 Islamic Home Financing Through Musharakah Mutanaqisah: A Crowdfunding Model

AHAMED KAMEEL Mydin Meera

12 Proposed Model on the Provision of Affordable Housing via Collaboration Between

Wakaf-Zakat-Private Developer - $537 / 72638$

KHAIRUDDIN Abdul Rashid,

SHARINA FARIHAH Hasan and

AZILA Ahmad Sarkawi

13 Shariah Compliance Risk-Sharing in Islamic Contracts

Masamitsu ONISHI and Kiyoshi KOBAYASHI

14 Takaful for Construction Works' Contract:

Concept and Application - 7388/72639

PUTERI NUR FARAH NAADIA Mohd Fauzi

and KHAIRUDDIN Abdul Rashid

15 Hibah $M u^{\prime}$ Allaqah (Conditional Gift) and Its Application in Takaful $2902 / 72640$

16 Managing the Risk of Insolvency in the Construction Industry with Equity Financing: Lessons from Nakheel ABDUL KARIM Abdullah

Index 


\section{About the Editors}

KHAIRUDDIN Abdul Rashid, Sr. Dip., BSc., MSc., Ph.D., MRISM, CQS (BQSM) is Professor at the Department of Quantity Surveying, Kulliyyah of Architecture and Environmental Design and Head, Procurement and Project Delivery System Research Unit, International Islamic University Malaysia (IIUM). He is co-founder and co-editor of the Journal of Quantity Surveying and Construction Business and reviewer of several international refereed journals related to construction. Professor Khairuddin has authored, coauthored, edited and co-edited 14 books and more than 200 technical papers on quantity surveying, procurement, contract administration including Shariah-compliant and Public Private Partnership (PPP) or Private Finance Initiative (PFI).

Kiyoshi KOBAYASHI, BSc., MSc., Eng.D., is Professor at the Graduate School of Management as well as Graduate School of Engineering, Kyoto University. He is a renowned researcher in the fields of Infrastructure Management and Regional Science and a recipient of several awards including the Distinguished Research Awards by Japan Society of Civil Engineers (JSCE) and Fellow Awards by RSA International. He is the President of JSCE, and serves on the editorial boards of international journals including the Journal of Infrastructure Systems. He is the author and co-editor of 65 books and over 430 academic reviewed papers. 
SHARINA FARIHAH Hasan, Dip., BSc., MSc. (Eng.), Ph.D. (Eng.), is Assistant Professor at the Department of Quantity Surveying, Kulliyyah of Architecture and Environmental Design, IIUM. She is an editorial board member of the Journal of Quantity Surveying and Construction Business. Dr. Sharina has authored and coauthored more than 40 papers in books, book chapters, journal articles and proceedings on quantity surveying, prequalification of contractors, labor market and productivity, and Shariah compliance in construction.

Masamitsu ONISHI, BSc., MSc., Eng.D., is Associate Professor at the Disaster Prevention Research Institute, Kyoto University. He is interested in institutional systems related to the procurement of infrastructure services including contracting and procurement schemes particularly PPPs and disaster risk governance. He is a recipient of the JSCE Young Researcher Award 2006 and Best Paper Award 2008. He has authored and co-authored more than 50 refereed papers and 12 books, chapters in books and proceedings.

\section{Contributors' Biographies}

ABDUL KARIM Abdullah (Leslie TEREBESSY), B.A. (Hons), M.A., M.Ed. is President of Terebessy Foundation, a think-tank based in Toronto, Canada (www.terebessyfoundation.com). He taught economics for 10 years in Canada and Malaysia. He published works on Islamic finance and economics. He co-edited Islamic Finance: Issues in Sukuk and Proposals for Reform, Islamic Foundation, UK, 2014, and Islamic Studies in World Institutions of Higher Learning, USIM, Malaysia, 2006. He is author of Issues in Islamic and Conventional Finance: A Critical Appraisal, forthcoming.

ABDUL MAJID TAHIR Mohamed, LL.B., Ph.D. is lecturer and Deputy Dean (Academic and Graduate) at the Faculty of Law and International Relations, University Sultan Zainal Abidin, Terengganu, Malaysia.

AHAMED KAMEEL Mydin Meera, B.A., M.A., Ph.D. is Professor and currently Managing Director of Z Consulting Group Sdn. Bhd. He has taught, researched, published and consulted in areas including Islamic Finance, Economics, Money and Payment Systems; and is particularly known for his writings on real money systems. He authored the books The Islamic Gold Dinar, Pelanduk Publications, 2002; The Theft of Nations, Pelanduk Publications, 2004; and Real Money, IIUM Press, 2009. 
AINUL JARIA Maidin, LL.B (Hons), LL.M, Ph.D. is Professor at the Ahmad Ibrahim Kulliyyah of Laws, IIUM. Her research interests are legal and administrative framework in the areas relating to sustainable development, disaster risk management, land administration and management, property, building construction and maintenance. She has authored and co-authored 60 books, chapters in books and conference proceedings.

AZILA Ahmad Sarkawi, B.A. (Hons), M.A., Ph.D. is Associate Professor at the Department of Urban and Regional Planning, IIUM. Her areas of specialization are planning and environmental laws and Islamic built environment. She received the Planning Scholar Award twice in 2009 and 2016. She has authored and co-authored more than 90 papers related to her areas of specialization.

AZMAN Mohd Noor, B.A. (Hons), M.A., Ph.D. is Associate Professor at the International Institute of Islamic Banking and Finance, IIUM. His research interests are on Islamic banking products, takaful (Islamic insurance) and Islamic capital market. He is Shariah committee member at a number of Islamic financial institutions in Malaysia.

Christopher Nigel PREECE, BSc., Ph.D. is Professor of Project Management at the College of Engineering, Abu Dhabi University. For 15 years Professor Preece was with the Construction Management Group at the School of Civil Engineering, University of Leeds, UK. From 2008 to 2010, he was with the Department of Quantity Surveying at the IIUM and from 2010 to 2015, he was with the Razak School of Engineering and Advanced Technology, Universiti Teknologi Malaysia. He is a recognized authority in international construction, project and business development and marketing. He is a Fellow of the Chartered Institute of Building and an international Construction Ambassador for the Chartered Institute of Building (CIOB). He is a Chartered Marketer and a Fellow of the Higher Education Academy, UK.

Etsuaki YOSHIDA, Eng.D. is Project Associate Professor at the Graduate School of Asian and African Area Studies of Kyoto University. He is also Director and Senior Economist at Japan Bank for
International Cooperation. His research interests are international finance, emerging economies, and Islamic finance from a practical point of view, including FinTech, macro-financial stability and product development. He has authored and co-authored five books on Islamic finance in Japanese and book chapters. Dr. Yoshida is a frequent speaker on Islamic finance in events including World Islamic Banking Conference, Islamic Financial Services Board (IFSB) seminar, and the Sukuk summit.

KHAIRUDDIN Abdul Rashid, Sr. Dip., BSc., MSc., Ph.D., MRISM, CQS (BQSM) is Professor at the Department of Quantity Surveying, Kulliyyah of Architecture and Environmental Design and Head, Procurement and Project Delivery System Research Unit, IIUM. He is co-founder and co-editor of the Journal of Quantity Surveying and Construction Business and reviewer of several international refereed journals related to construction. Professor Khairuddin has authored, co-authored, edited and co-edited 14 books and more than 200 technical papers on quantity surveying, procurement, contract administration including Shariah-compliant and Public Private Partnership (PPP) or Private Finance Initiative (PFI).

Kiyoshi KOBAYASHI, BSc., MSc., Eng.D. is Professor at the Graduate School of Management as well as Graduate School of Engineering, Kyoto University. He is a renowned researcher in the fields of Infrastructure Management and Regional Science and a recipient of several awards including the Distinguished Research Awards by JSCE and Fellow Awards by RSA International. He is the President of JSCE, and serves on the editorial boards of international journals including the Journal of Infrastructure Systems. He is the author and co-editor of 65 books and over 430 academic reviewed papers.

M. KAMAL Hassan, B.A., M.A., MPhil., Ph.D. is Distinguished Professor, International Islamic University Malaysia (IIUM). He joined IIUM since its inception in 1983, becoming the Founding Dean of the Kulliyyah of Islamic Revealed Knowledge and Human Sciences, Deputy Rector for Academic Affairs and Rector. He specializes in contemporary Islamic thought with special reference to Southeast Asia. His publications focus on the concept of integrated education, 
islamization of human knowledge, Islamic ethics in contemporary society and the concept of Islamic moderation in the Malay world.

Masamitsu ONISHI, BSc., MSc., Eng.D. is Associate Professor at the Disaster Prevention Research Institute, Kyoto University. He is interested in institutional systems related to the procurement of infrastructure services including contracting and procurement schemes particularly PPPs and disaster risk governance. He is a recipient of the JSCE Young Researcher Award 2006 and Best Paper Award 2008. He has authored and co-authored more than 50 refereed papers and 12 books, chapters in books and proceedings.

MOHAMAD AKRAM Laldin, B.A. (Hons), Ph.D. is Professor and currently the Executive Director of International Shari'ah Research Academy for Islamic Finance (ISRA), Malaysia. His research interests are Islamic banking and finance, Islamic capital market, takaful and fundamentals of Islamic jurisprudence. He was recipient of the Zaki Badawi Award for Excellence in Shariah Advisory and Research in 2010 and recipient for Most Outstanding Individual Contribution to Islamic Finance during the Kuala Lumpur Islamic Finance Forum (KLIFF) in 2016. He has authored and co-authored several books.

PUTERI NUR FARAH NAADIA Mohd Fauzi, BSc., Ph.D. is Assistant Professor at the Department of Quantity Surveying, Kulliyyah of Architecture and Environmental Design, IIUM. She is a Graduate Member of Board of Quantity Surveyors Malaysia (BQSM) and Registered Member of Royal Institution of Surveyors Malaysia (RISM) and a member of the Procurement and Project Delivery System Research Unit at IIUM. She has published works on takaful for construction works, Shariah-compliant construction contracts, procurement and quantity surveying.

ROZINA Zafian, BSc., MSc., Ph.D., MRISM, BQSM is Senior Superintending Quantity Surveyor at the Contract and Quantity Surveying Division, Public Works Department, Malaysia.

SHARINA FARIHAH Hasan, Dip., BSc., MSc. (Eng.), Ph.D. (Eng.) is Assistant Professor at the Department of Quantity Surveying,
Kulliyyah of Architecture and Environmental Design, IIUM. She is an editorial board member of the Journal of Quantity Surveying and Construction Business. Dr. Sharina has authored and coauthored more than 40 papers in books, book chapters, journal articles and proceedings on quantity surveying, prequalification of contractors, labor market and productivity, and Shariah compliance in construction.

ZUHAIRAH ARIFF Abd Ghadas, LL.B (Hons), LL.M, Ph.D. is Professor at the Faculty of Law and International Relations, University Sultan Zainal Abidin, Terengganu, Malaysia. Her area of specialization is in Business Law, particularly on development of business entities. She has won gold medals in innovation and research competitions at the university level and silver medals at the International Invention, Innovation and Technology Exhibition (ITEX) in 2015 and 2017. 


\section{Shariah Compliance in Construction Contracts, Project Finance and Risk Management}

The application of Shariah compliance in business transactions continues to increase. The Asian financial crisis of 1997, global financial crisis of 2007-2008, Enron scandal and other reported ills besieging conventional business transactions have led to advocates of Shariah-compliant business transactions promoting the latter as a credible alternative. However, unlike the banking, commerce and financial sectors, the uptake by the construction sector was sluggish due to limited understanding of Shariah among the practitioners and policymakers compounded by the lack of research and publications on its application for the construction sector.

This book is intended for students, researchers, practitioners and policymakers of the construction industry as well as the related upstream and downstream activities. It offers basic theories, challenges current practices, and proposes innovative ideas on Shariah compliance and its application for the construction industry. 